\title{
Partisipasi Masyarakat pada Penerapan Pembangunan Pariwisata Berkelanjutan (Studi Kasus Desa Wisata Pujon Kidul, Kabupaten Malang)
}

\author{
Widyarini S. Ira', Muhamad² \\ ${ }^{1}$ Magister Kajian Pariwisata, Sekolah Pasca Sarjana, Universitas Gadjah Mada \\ widyarini.s.ira@gmail.com \\ ${ }^{2}$ Magister Kajian Pariwisata, Sekolah Pasca Sarjana, Universitas Gadjah Mada \\ drmuhammad@ugm.ac.id
}

\begin{abstract}
Tourism village is a form of tourism destination development that is widely chosen in the development of sustainable tourism because it is considered successful in responding to current demands, proven in efforts to improve economic welfare, develop tourism potential in the community, and show active involvement of the community in tourism development in their area. This paper aims to demonstrate the achievements of the rural tourism community through the Sadar Wisata Group in the application of sustainable tourism development, in terms of increasing economic levels, especially in income and changes in various jobs of citizens. Pujon Kidul Tourism Village, Malang Regency, East Java was chosen as the location for the case studies conducted, with the research method used was a qualitative descriptive model and in-depth interviews were conducted with villagers. The results obtained are, Pokdarwis Pujon Kidul Tourism Village has succeeded in building and developing the tourism potential possessed through the implementation of sustainable tourism development in the countryside. This success is shown by the increase in community income and changes in the various occupations of the villagers who were originally farmers to become entrepreneurs.
\end{abstract}

Kata kunci: Community Participation, Sadar Wisata Group, Sustainable Tourism Development 


\section{PENDAHULUAN}

Pariwisata telah menjadi perhatian utama dunia, dengan fokus pengembangan destinasi ke arah pembangunan pariwisata berkelanjutan, yakni pengembangan lebih berpusat pada keberlangsungan destinasi pariwisata, kepentingan masyarakat dan pengaruh lingkungan dimana destinasi tersebut berada.

Menurut UNWTO, Pariwisata berkelanjutan merupakan pembangunan pariwisata yang memperhitungkan penuh dampak ekonomi, sosial dan lingkungan masa sekarang dan mendatang, dengan memenuhi kebutuhan wisatawan, industri pariwisata, lingkungan dan masyarakat local, meliputi aspek; (1) optimalisasi kemanfaatan sumber daya alam, melalui pemeliharaan proses ekologi penting dan pelestarian alam serta keanekaragaman hayati, (2) menghormati keaslian sosial budaya masyarakat lokal, pelestarian warisan budaya dan nilai tradisi, serta kontribusi pada pemahaman dan toleransi antarbudaya, (3) memastikan kelayakan keberlanjutan usaha ekonomi jangka panjang, kemanfaatan sosio-ekonomi yang merata pada semua pemangku kepentingan, termasuk peluang kerja, pendapatan yang berkesinambungan serta layanan sosial kepada masyarakat lokal, dan pengentasan kemiskinan. Salah satu wujud penerapan pembangunan pariwisata berkelanjutan adalah melalui desa wisata.

Desa wisata menurut Nuryanti (Kemenpar), merupakan sebuah daerah tujuan wisata dapat disebut pula destinasi pariwisata,dimana merupakan gabungan dari daya tarik wisata, amenitas, akomodasi, aksesibilitas, yang dikemas dalam suatu sajian struktur kehidupan masyarakat dengan tata cara dan tradisi yang berlaku. Kemasan ini bertujuan untuk meningkatkan minat kunjungan dan lama tinggal wisatawan, serta memperkenalkan budaya desa secara lebih dekat, juga melakukan aktivitas masyarakat lokal; yang banyak disebut sebagai atraksi pariwisata pedesaan.

Pariwisata pedesaan menurut Hadiwijoyo (2012), merupakan pariwisata yang dapat dilihat sebagai suatu pemukiman dengan fasilitas lingkungan yang sesuai dengan tuntutan wisatawan dalam menikmati, mengenal, dan menghayati kekhasan desa dengan segala daya tariknya serta tuntutan kegiatan hidup bermasyarakat.

Pengembangan desa wisata berkaitan erat dengan partisipasi masyarakat desa wisata, utamanya pada dampak langsung pembangunan pariwisata di lingkungan sekitar. Partispasi aktif dari masyarakat diperlukan guna meminimalisir dampak negatif yang terjadi. Dalam hal ini Kelompok Sadar Wisata (Pokdarwis) sebagai bentuk perwakilan dari masyarakat desa harus aktif dalam berbagai hal, sehingga dampak negatif untuk lingkungan dan ekosistem pada desa dapat dihindari.

Salah satu desa wisata yang mulai mencuri perhatian saat ini, adalah Desa Wisata Pujon Kidul Kab. Malang melalui prestasinya dalam memenangi penghargaan dari Kementerian Parwisata pada tahun 2017 lalu dengan kategori Pokdarwis Mandiri, Peringkat Terbaik I untuk Kegiatan Usaha Masyarakat Bidang Pariwisata.

Desa Wisata Pujon Kidul merupakan salah satu desa yang berada wilayah 
Kecamatan Pujon, Kabupaten Malang, Jawa Timur. Desa ini merupakan desa agraris, dimana 50\% lebih wilayahnya (171.844 Ha) adalah sawah dan ladang, sehingga sebagian besar mata pencaharian penduduknya adalah petani. Daerah desa ini berbatasan langsung dengan Kota Batu serta wilayah Perhutani yang berfungsi sebagai hutan konservasi dan produksi, dengan tanaman komoditas berupa rumput gajah dan pinus. Potensi pertanian dengan lahan yang demikian luas, belum berdampak optimal secara ekonomis bagi warga, karena harga panen yang fluktuatif serta proses distribusi yang berliku.

Dengan semangat guna meningkatkan kondisi ekonomi warga melalui potensi pariwisata, para pengurus desa dan sebagian masyarakat yang peduli wisata, membentuk rintisan awal Pokdarwis Capung Alas Desa Wisata Pujon Kidul Kab. Malang.

Berkaitan dengan prestasi Pokdarwis Capung Alas Pujon Kidul tersebut, penulis ingin mengetahui lebih lanjut mengenai partisipasi masyarakat, utamanya dalam Pokdarwis, pada penerapan pembangunan pariwisata berkelanjutan.

\section{KERANGKA TEORI}

Purmada (2013) menyatakan bahwa, pariwisata berbasis masyarakat (Community Based Tourism/CBT) merupakan konsep pengelolaan kepariwisataan dengan mengedepankan partisipasi aktif masyarakat, bertujuan untuk memberikan kesejahteraan serta tetap menjaga kualitas lingkungan, juga melindungi kehidupan sosial budaya. Konsep pariwisata berbasis berbasis masyarakat berkesesuaian dengan pariwisata berkelanjutan (sustainable tourism) yang memerlukan partisipasi masyarakat.

Dalam pengembangan suatu destinasi wisata terdapat 7 fase tahapan, yaitu meliputi eksplorasi, keterlibatan, pengembangan, konsolidasi, stagnasi, penurunan, dan perbaikan (Butler dalam Pitana 2005). Keseluruhan tahapan tersebut memerlukan partisipasi aktif masyarakat. Pada kebanyakan Desa Wisata, masyarakat diwakili oleh sebuah lembaga Pokdarwis.

Pokdarwis merupakan salah satu pemangku kepentingan yang berperan dalam suatu Desa Wisata. Sebagai kelompok penggerak pariwisata, Pokdarwis merupakan salah satu bentuk kelembagaan informal beranggotakan masyarakat, dengan kesamaan tujuan untuk mengembangkan pariwisata, juga merupakan salah satu unsur pemangku kepentingan dalam masyarakat yang memilki keterkaitan dan peran penting dalam mengembangkan dan mewujudkan Sadar Wisata (Kemenparekraf, 2012, 6).

Peran kelompok masyarakat di Desa Wisata menunjukkan adanya partisipasi masyarakat dalam pembangunan dan pengembangannya. Adisasmita (2006) mengemukakan, bahwa Partisipasi Masyarakat adalah suatu pemberdayaan masyarakat melalui peran dan kegiatan penyusunan perencanaan serta implementasi program pembangunan, juga merupakan aktualisasi dari kesediaan dan kemauan atau kemampuan masyarakat untuk berkorban serta berkontribusi terhadap implementasinya.Terdapat 4 bentuk 
partisipasi masyarakat yaitu, (1) Partisipasi buah piker, dengan pelibatan masyarakat berupa sumbangan ide terkait kekurangan atau kelebihan desa wisata, (2) Partisipasi tenaga fisik, pelibatan masyarakat secara fisik pada pembangunan fasilitas-infrasruktur desa, (3) Partisipasi keterampilan dan kemahiran masyarakat, berupa keterlibatan pada pengembangan usaha penunjang atraksi desa wisata (4) Partisipasi harta benda merupakan keterlibatan pasif masyarakat melalui kontribusi asset pribadi (Dirjen PMD Direktorat Jendral Pembangunan Masyarakat Desa Depdagri dalam Sudriamunawar, 2006). Dari variablevariabel inilah, partisipasi masyarakat dapat terukur dan terlihat pada implementasi pembangunan dan pengembangan suatu desa wisata.

\section{METODE PENELITIAN}

Penelitian ini menggunakan model penelitian kualitatif deskriptif serta wawancara mendalam (in-depth interview) yang dilakukan pada warga desa. Penelitian dilakukan di Desa Wisata Pujon Kidul Kab. Malang. Metode kualitatif dengan mengolah dan mendeskripsikan data primer berupa hasil wawancara dengan perangkat dan masyarakat Desa Wisata Pujon Kidul, ditambah pengolahan data sekunder berupa angka kunjungan dan data lainnya.

\section{DESA WISATA PUJON KIDUL}

Desa Wisata Pujon Kidul, merupakan salah satu desa yang terletak di Kecamatan Pujon, Kabupaten Malang, Jawa Timur. Letaknya yang berbatasan langsung dengan destinasi wisata Kota Batu, menyebabkan desa agraris ini menerima kelimpahan wisatawan dari daerah tersebut.
Desa Wisata Pujon Kidul memiliki batas administratif, yaitu: Desa Ngroto dan Pujon Lor di sebelah utara; Desa Pujon Lor dan Desa Pandesari sebelah timur, Wilayah Hutan Perhutani di sebelah selatan, dan Desa Sukomulyo di sebelah barat.

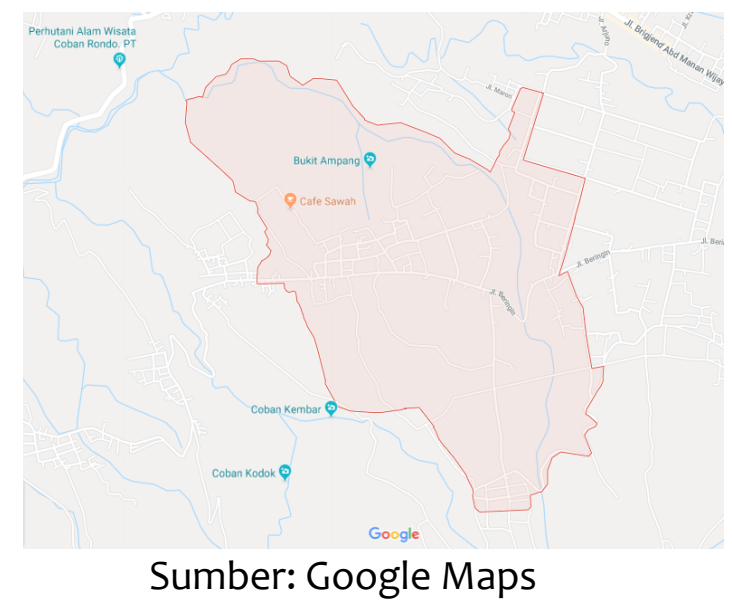

Desa Wisata Pujon Kidul masuk wilayah Kecamatan Pujon, Kabupaten Malang, Jawa Timur dan memiliki luas wilayah 330.000 hektar (Data Desa Pujon Kidul, 2018). Kepadatan penduduk mencapai 4.486 jiwa dan merupakan penduduk tetap (SIE Desa Wisata Pujon Kidul, April 2018, pemutakhiran 6 April 2018). Keluasan wilayah yang potensial tersebut, banyak potensi sumber daya alam yang belum dieksplorasi hingga saat ini.

Pariwisata daerah ini mulai berkembang tahun 2013, saat sekelompok masyarakat sebagai cikal bakal Pokdarwis di Desa Wisata Pujon Kidul mengeksplorasi daya Tarik wisata Air Terjun Sumber Pitu. Mereka ingin meningkatkan kehidupan ekonomi, karena hasil pertanian tidak bisa memberikan hasil yang memadai. Upaya tersebut dilakukan dengan perbaikan akses dan infrastruktur. Potensi wisata itu berpadu dengan komoditas pertanian warga, serta aktivitas edukasi wisata alam, yaitu 
kegiatan konservasi dan pemanfaatan sumber daya alam bagi masyarakat. Tahun 2014, Perhutani terlibat dalam pengelolaan wisata Air Terjun Sumber Pitu. Hal itu dirasa tidak berpihak pada masyarakat, khususnya dari segi pendapatan (wawancara dengan Sekretaris Pokdarwis Bapak Anas Taufik, 6 April 2018). Desa Pujon Kidul pun menarik diri dari pengelolaan wisata tersebut, dan mengeksplorasi potensi wisata lain untuk peningkatan taraf ekonomi masyarakat.

Dinas Kebudayaan dan Pariwisata Kab. Malang giat membina masyarakat Desa Pujon Kidul, hingga lahir Pokdarwis Capung Alas yang bertujuan membangun potensi wisata desa untuk peningkatan taraf ekonomi masyarakat. Pokdarwis berupaya menghidupkan kegiatan usaha pariwisata melalui pengelolaan usaha wisata dengan membentuk 6 divisi usaha, yaitu; Humas dengan tugas untuk publikasi, Marketing untuk pemasaran obyek, Homestay untuk fasilitas akomodasi, Pertanian dan Peternakan guna mengelola atraksi wisata bertani dan beternak, serta Home Industry bertanggung jawab untuk pengelolaan dan pengembangan olahan komoditas Desa Pujon Kidul seperti olahan susu, buah dan sayur. Di tahun berikutnya perkembangan atraksi, akses, amenitas dan akomodasi di daerah ini semakin meningkat. Café Sawah merupakan salah satu amenitas sekaligus atraksi yang ada. Atraksi wisata yang ditawarkan adalah swafoto, memadukan lanskap pemandangan area pertanian sebagai latar foto, serta pendopo sebagai pusat kegiatan Café Sawah.
Pokdarwis melibatkan partisipasi masyarakat aktif melalui tatap muka langsung di setiap kesempatan, serta masukan berupa buah pikir. Seperti pengenalan standardisasi kebersihan di awal usaha wisata.

Pengembangan atraksi wisata Desa Pujon Kidul, dilakukan dengan mempertahankan suasana asli pedesaan sebagai daya tarik utama. Model bangunan asli pedesaan yang ramah alam dan sosial digunakan, karena karena menggunakan material dari lingkungan sekitar, dan tetap melestarikan lingkungan Desa Pujon Kidul dan sumber daya alamnya. Ramah sosial, karena partispasi fisik dari masyarakat untuk turut membangun fasilitas yang ada.

Wisata edukasi alam sebagai atraksi Pujon Kidul makin berkembang, mengakibatkan peningkatan angka kunjungan wisatawan yang berdampak pada pendapatan desa. Pokdarwis kemudian mengembangkan atraksi wisata lain yaitu Café Sawah, yaitu fasilitas untuk beristirahat serta menikmati sajian kuliner khas dari Desa Pujon Kidul. Café sawah berdiri melalui partisipasi fisik penduduk pada tahap konsolidasi dengan lembaga terkait dalam hal ini Bank BNI. Penyederhanaan retribusi dengan system cashback voucher juga berpengaruh, pengunjung tidak perlu membayar berkali-kali untuk tiket masuk dan biaya parker. Cukup membayar retribusi Rp. 8.000,- di pintu masuk, dapat menikmati sajian kuliner di Café Sawah. Pengunjung hanya perlu membayar selisih jika pembelian melebihi nominal voucher tersebut. 
Dari nominal sebesar Rp. 8.000,tersebut pemasukan desa dapat digambarkan sebagai berikut:

Tabel 1

Gambaran Pemasukan Desa Wisata Pujon Kidul

\begin{tabular}{|l|l|}
\hline Biaya cetak & Rp. 1.000,- \\
\hline Parkir mobil/motor & $\begin{array}{l}\text { Rp. 4500 atau Rp. } \\
1500\end{array}$ \\
\hline Voucher makan & Rp. 3000 \\
\hline $\begin{array}{l}\text { Kontribusi Makanan } \\
\text { café sawah (dari } \\
\text { voucher makan) }\end{array}$ & Rp. 2500 \\
\hline $\begin{array}{l}\text { Pemasukan desa wisata } \\
\text { dari makanan }\end{array}$ & 20\% dari Rp. 2500,- \\
\hline
\end{tabular}

Data dari wawancara dengan Kepala Desa Bapak Udi Hartoko

Dari tabel diatas dapat dilihat pemasukan untuk Desa Wisata Pujon Kidul dan masyarakat yang terlibat dalam penyediaan layanan makanan dan minuman di Café Sawah. Pemasukan diatas tidak dinyatakan dalam prosentase, karena telah menjadi kesepakatan dari masyarakat dan Pokdarwis selaku pengelola, serta lebih mudah dimengerti oleh masyarakat umum. Hal tersebut juga terjadi dalam pemasukan dari akomodasi (live in maupun homestay) dan dari bidang lainnya.

Akumulasi hasil pendapatan, ini selain dimuat di situs resmi Desa Wisata Pujon kidul (www.sie.pujonkidul.desa.id), juga dilaporkan secara berkala dalam pertemuan rutin. Alasan ditampilkannya laporan pemasukan dan laporan keuangan lainnya, agar dapat diakses semua kalangan, baik masyarakat maupun wisatawan.

Tanggal 10 Agustus 2016, Desa Pujon Kidul dicanangkan oleh Bupati Malang menjadi Desa Wisata Pujon Kidul. Pada acara tersebut, Pokdarwis mengembangkan atraksi baru yaitu Festival Lampu Oblik, festival tahunan yang memadukan sajian makanan tradisional dengan budaya atau permainan tempo dulu, dilakukan bersamaan dengan upacara bersih desa. Tujuannya selain memelihara tradisi, juga meningkatkan lama tinggal wisatawan di Desa Wisata Pujon Kidul. Masyarakat berpartisipasi penuh pada acara ini. Mulai dari pengusulannya di Rapat Desa hingga pelaksanaan, juga ketika wisatwan menginap hingga meninggalkan desa.

TABEL 2 Kunjungan Wisatawan Desa Wisata Pujon Kidul (2015-2017)

\begin{tabular}{|l|l|l|}
\hline \multicolumn{1}{|c|}{ Tahun } & \multicolumn{1}{c|}{ Wisman } & \multicolumn{1}{c|}{ Wisnus } \\
\hline 2015 & 27 & 15,150 \\
\hline 2016 & 26 & 15,710 \\
\hline 2017 & 148 & 320,209 \\
\hline
\end{tabular}

Sumber : Kebudayaan dan Pariwisata Jawa timur dalam Angka 2015-2017, Disbudpar Jatim

Dari tabel 2, terlihat peningkatan signifikan dari angka kunjungan wisatawan ke pujon kidul dari tahun ke tahun. Tahun 2017 menunjukkan peningkatan yang berarti, karena kunjungan wisatawan mencapai dua kali lipat angka kunjungan tahun sebelumnya.

Kurang lebih 600 wisatawan berkunjung setiap harinya pada hari biasa. Jumlah ini meningkat drastis di akhir minggu dan hari libur hingga mencapai 1.500 sampai 2.000 orang pengunjung. Puncaknya angka kunjungan dapat mencapai 4.000 orang wisatawan.

Pengelolaan dan implementasi Usaha Pariwisata Desa Wisata Pujon Kidul hingga kini telah melibatkan kurang lebih 2.000 orang anggota masyarakat 
atau hampir $50 \%$ jumlah penduduk. Hal ini merupakan bukti partisipasi masyarakat juga bukti pencapaian tujuan dari Pokdarwis untuk memberdayakan masyarakat desa terutama golongan pekerja produktif. Usaha pariwisata yang ada semakin baik pengelolaanya, terbukti dengan merampingnya divisi usaha yaitu Humas, Marketing, Live In (bertanggung jawab atas pengelolaan homestay, pertanian, peternakan home industry dan atraksi budaya) serta divisi café sawah. Penggunaan teknologi informasi juga dioptimalkan, dengan melibatkan generasi muda dengan membentuk tenaga system informasi yang ada di setiap RT.

Desa Wisata Pujon Kidul yang terdiri dari 3 dusun yaitu Krajan, Maron dan Tulungrejo. Jumlah penduduk terbesar ada di Dusun Krajan sebanyak 3.177 jiwa dari total 4.486 jiwa (Data tahun 2018, SIE Pujon Kidul), yang juga merupakan pusat kegiatan dari usaha pariwisata. Penduduk dengan usia produktif mencapai $45 \%$ dari jumlah seluruh penduduk (Data tahun 2018, SIE Pujon KIdul). Angka tersebut juga mewakili jumlah Tenaga Kerja yang terdapat di Desa Wisata Pujon Kidul yang potensial.

Tabel DATA PENDUDUK desa wisata pujon kidul TAHUN 2018

\begin{tabular}{|l|c|}
\hline RENTANG UMUR & $\begin{array}{c}\text { JUMLAH PENDUDUK } \\
\text { (ORANG) }\end{array}$ \\
\hline Umur $0-5$ & 334 \\
\hline Umur $6-12$ & 463 \\
\hline Umur $13-17$ & 352 \\
\hline Umur $18-45$ & 2014 \\
\hline Diatas 45 & 1309 \\
\hline
\end{tabular}

Data 2018

(http://www.sie.pujonkidul.desa.id/pen duduk.php)
Dari tabel diatas, dapat dilihat penduduk dengan usia produktif yaitu antara 18-45 tahun, berjumlah cukup besar yaitu 2.014 jiwa atau kurang lebih $50 \%$ dari jumlah penduduk total.

Sedang ragam mata pencaharian warga terlihat pada tabel berikut ini

Tabel 3 Data Mata Pencaharian Warga

\begin{tabular}{|l|r|}
\hline \multicolumn{1}{|c|}{ PEKERJAAN } & $\begin{array}{r}\text { JUMLAH } \\
\text { PENDUDUK }\end{array}$ \\
\hline Petani/Pekebun & 1368 \\
\hline Belum / Tidak Bekerja & 961 \\
\hline Ibu Rumah Tangga & 727 \\
\hline Pelajar/Mahasiswa & 665 \\
\hline Wiraswasta & 313 \\
\hline Buruh Tani/Perkebunan & 148 \\
\hline Karyawan Swasta & 82 \\
\hline Peternak & 58 \\
\hline Perdagangan & 27 \\
\hline Pedagang & 23 \\
\hline Buruh Harian Lepas & 19 \\
\hline Guru & 19 \\
\hline Buruh Peternakan & 10 \\
\hline Lainnya & 48 \\
\hline Jumlah & 4468 \\
\hline
\end{tabular}

Sumber: SIE Pujon Kidul, 2018

Dari Tabel Data Mata Pencaharian tersebut terlihat bahwa 31\% dari penduduk Desa Wisata Pujon Kidul merupakan petani, sedang Penduduk yang tidak bekerja sebesar $21 \%$. Jumlah penduduk dengan usia produktif yang tidak bekerja, dapat menimbulkan permasalahan sosial. Pengembangan aktif usaha pariwisata yang berbasis masyarakat terus dilakukan, untuk dapat menanggulangi masalah ini. Jumlah penduduk yang terlibat langsung, juga diharapkan terus meningkat. Di bagian sebelumnya telah disebutkan bahwa, usaha pariwisata yang dilakukan di Desa Wisata Pujon Kidul melibatkan kurang lebih 2.000 orang penduduk. Angka ini diharapkan terus meningkat, tidak hanya berasal dari satu daerah saja, tapi meluas ke daerah lainnya. 
Partisipasi masyarakat secara penuh dilakukan secara terus menerus, di rapat desa periodik maupun kesempatan lain. Desa Wisata Pujon Kidul masih menggunakan tatap muka langsung, sebagai upaya mengoptimalkan partisipasi masyarakat, hingga proses monitoring dan evaluasi. Aktivitas usaha pariwsata yang semakin pesat menuntut penggunaan Sistem Teknologi Informasi melalui computer, untuk proses monitoring evaluasi secara luas. Aktivitas tersebut juga melibatkan partisipasi masyarakat langsung, seperti monitoring hasil pencatatan penerimaan wisata.

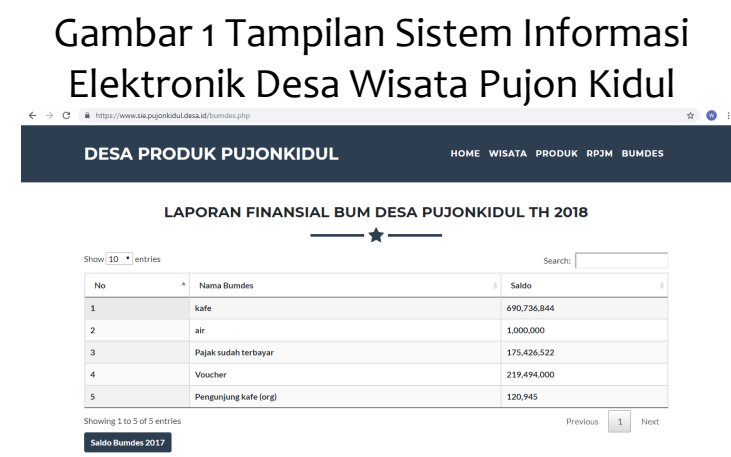

Sumber: SIE Desa Wisata Pujon Kidul, 2018

Masih banyak tenaga kerja produktif yang berpendidikan rendah di desa wisata pujon kidul. Hal ini diatasi oleh Desa Wisata Pujon Kidul dengan memberikan pelatihan-pelatihan yang menunjang terutama di bidang pariwisata, melalui kerjasama dengan institusi terkait sperti Dinas Kebudayaan dan Pariwisata Kab. Malang.

Desa wisata Pujon Kidul semakin dikenal setelah memenangi penghargaan 10 desa wisata terbaik dari Kementerian Desa Pembangunan Daerah Tertinggal dan Transmigrasi, dengan kategori desa wisata agro pada tahun 2017 lalu. Desa Wisata Pujon Kidul berhasil mengangkat kehidupan agrowisata menjadi berbagai atraksi wisata yang menarik. Pokdarwis Capung Alas Desa Wisata Pujon Kidul juga meraih penghargaan dari Kementerian Pariwisata untuk Pokdarwis Mandiri pada kegiatan usaha masyarakat bidang pariwisata.

Saat ini Desa Wisata Pujon Kidul sedang bersiap mengikuti Indonesia Sustainable Tourism Award (ISTA) 2018, sebuah penghargaan yang mengapresiasi keberlanjutan suatu destinasi wisata, yang salah satu parameternya adalah partisipasi dan keterlibatan masyarakat secara utuh. Desa wisata pujon kidul telah menerapkannya dari mulai berdirinya usaha wisata disana.

Sebagai sebuah destinasi wisata, Desa Wisata Pujon Kidul wajib menyediakan sarana akomodasi untuk wisatawan. Ada 60 homestay di Desa Wisata Pujon Kidul dengan harga mulai 150 ribu hingga 250 ribu rupiah, perkamar perhari. Homestay ini merupakan kamar di rumah penduduk yang disewakan pada wisatawan. Partisipasi masyarakat dituntut penuh disini, karena menerima wisatawan bukan hal mudah, serta ada standardisasi pelayanan yang harus dipenuhi. Melalui sosialisasi dan pelatihan yang dilakukan pada penduduk, hingga kini telah terdapat 2 jenis homestay yang diusahakan di Desa Wisata Pujon Kidul, yaitu;

1. Homestay dengan SOP (Standard Operation Procedure)

SOP disini terutama mengenai fasilitas yang diberikan, bukan dari segi pelayanan karena Desa Wisata Pujon Kidul telah memegang sertifikasi homestay dengan Standar ASEAN. Standar yang diberikan adalah fasilitas 
kamar setingkat hotel melati, dengan penyeragaman oleh Pokdarwis. Hingga saat ini, homestay yang telah memenuhi SOP tersebut, telah mencapai jumlah 33 buah homestay dengan kapasitas 65 kamar.

2. Homestay tanpa SOP

Akomodasi ini belum memiliki fasilitas kamar yang seragam, seperti perabotan, kelengkapan tempat tidur, dan lainnya, serta hingga saat ini berjumlah 27 buah.

\section{HASIL DAN KESIMPULAN}

Partisipasi masyarakat, merupakan pemberdayaan masyarakat lewat kontribusi peran dan kegiatan mulai penyusunan perencanaan sampai implementasi program pembangunan, serta bukti kesukarelaan dan komitmen masyarakat untuk berkorban serta $\begin{array}{lrr}\text { terlibat } & \text { dalam } & \text { penerapannya } \\ \text { (Adisasmita } & \text { 2006). } & \text { Partisipasi }\end{array}$ masyarakat berbentuk partisipasi buah pikir, partisipasi tenaga fisik, partisipasi keterampilan dan kemahiran masyarakat, partisipasi harta benda (Dirjen PMD Direktorat Jendral Pembangunan Masyarakat Desa Depdagri dalam Sudriamunawar, 2006). Dari variable-variabel inilah partisipasi masyarakat dapat terukur dan terlihat pada implementasi pembangunan dan pengembangan suatu desa wisata.

Partisipasi masyarakat dalam penerapan pariwisata berkelanjutan terlihat dari keterlibatan mereka pada usaha-usaha pariwisata yang dijalankan oleh Pokdarwis Capung alas. Keterlibatan mereka terlihat dalam halhal sebagai berikut; 
Tabel 4 Bentuk Partisipasi masyarakat pada usaha pariwisata Pokdarwis Capung Alas

\begin{tabular}{|c|c|c|c|c|c|}
\hline \multirow{2}{*}{$\begin{array}{l}\mathrm{N} \\
\mathrm{O} .\end{array}$} & \multirow{2}{*}{$\begin{array}{l}\text { Divisi } \\
\text { usaha } \\
\text { pariwisata }\end{array}$} & \multicolumn{4}{|c|}{ Bentuk Partisipasi } \\
\hline & & $\begin{array}{l}\text { Partisipasi Buah } \\
\text { Pikir }\end{array}$ & $\begin{array}{l}\text { Partisipasi } \\
\text { Tenaga Fisik }\end{array}$ & $\begin{array}{c}\text { Partisipasi } \\
\text { Keterampilan Dan } \\
\text { Kemahiran } \\
\text { Masyarakat }\end{array}$ & $\begin{array}{l}\text { Partisipasi Harta } \\
\text { Benda }\end{array}$ \\
\hline 1. & Humas & \multirow[b]{2}{*}{$\begin{array}{l}\text { Masyarakat terlibat } \\
\text { aktif pada usaha } \\
\text { publikasi obyek } \\
\text { wisata, dengan } \\
\text { keikutsertaan } \\
\text { mereka pada } \\
\text { pengelolaan } \\
\text { Sistem Informasi } \\
\text { Elektronik Desa } \\
\text { Pujon KIdul } \\
\text { Disampaikan } \\
\text { secara langsung } \\
\text { mellaui tatap muka } \\
\text { maupun melalui } \\
\text { SIE Desa Wisata } \\
\text { Pujon KIdul }\end{array}$} & \multirow[b]{2}{*}{$\begin{array}{l}\text { Jumlah } \\
\text { masyarakat } \\
\text { yang terlibat } \\
\text { langsung di } \\
\text { usaha } \\
\text { Pokdarwis } \\
\text { maupun tidak } \\
\text { langsung } \\
\text { meningkat, } \\
\text { mencapai } \\
\text { jumlah 2.000 } \\
\text { orang saat ini }\end{array}$} & Tidak ada & Tidak ada \\
\hline 2. & Marketing & & & & \\
\hline 3. & Live in & & \multirow{2}{*}{$\begin{array}{l}\text { Masyarakat } \\
\text { terlibat aktif } \\
\text { dalam } \\
\text { penyediaan } \\
\text { atraksi- } \\
\text { amenitas (Café } \\
\text { Sawah) } \\
\text { aksesibilitas, } \\
\text { dan akomodasi } \\
\text { (homestay) } \\
\text { untuk } \\
\text { wisatawan }\end{array}$} & \multirow{2}{*}{$\begin{array}{l}\text { Partisipasi yang } \\
\text { diberikan masyarakat } \\
\text { dalam mendorong } \\
\text { aneka ragam bentuk } \\
\text { usaha dan industri, } \\
\text { terlihat pada } \\
\text { diferensiasi produk } \\
\text { Desa Wisata Pujon } \\
\text { kidul. Perubahan dari } \\
\text { potensi wisata alam } \\
\text { Air Terjun menjadi } \\
\text { wisata edukasi dan } \\
\text { Café Sawah, juga } \\
\text { penyediaan kuliner } \\
\text { jhas Pujon kidul yag } \\
\text { menjadi sajian di Café } \\
\text { Sawah. }\end{array}$} & $\begin{array}{l}\text { Masyarakat secara } \\
\text { sukarela mengikuti } \\
\text { standardisasi } \\
\text { akomodasi } \\
\text { homestay dengan } \\
\text { membiayai } \\
\text { pengadaan } \\
\text { amenitas kamar. }\end{array}$ \\
\hline 4. & $\begin{array}{l}\text { Café } \\
\text { Sawah }\end{array}$ & & & & \\
\hline
\end{tabular}

Sumber: Wawancara Bapak Anas, Pokdarwis Capung Alas Pujon Kidul 
Pokdarwis Capung Alas mengelola potensi wisata melalui usaha pariwisata melalui divisi di BUMdes meliputi unit usaha, yaitu humas, marketing, live in dan café sawah. Keberhasilan pengelolaan terlihat dari kunjungan wisatawan dan pendapatan desa yang meningkat signifikan. Angka kunjungan wisatwan pada tahun 2015 tercatat 15.177 orang wisatawan, meningkat di tahun 2016 sejumlah 15.736, serta meningkat menjadi 2 kali lipat sejumlah 320.357 kunjungan di tahun 2017 (Disbudpar Jatim, 2015-2017).

Dari tabel 4, dijelaskan bentuk partipasi masyarakat Desa Wisata Pujon Kidul lewat keterlibatan mereka pada usaha pariwisata yang dijalankan Pokdarwis Capung Alas. Di tahun 2017 Pokdarwis melibatkan kurang lebih 2.000 orang pada usaha pariwisata yang dibina. Angka tersebut diluar anggota Pokdarwis dan pelaku usaha pariwisata langsung yang berjumlah 200 orang. Angka ini akan terus berkembang. Karena pada tahun 2018, Desa Wisata Pujon Kidul mengambil tema pengembangan Perluasan Dampak Ekonomi ke desa dan daerah lain disekitarnya. Hal ini tertuang dalam RPJMD Desa yang dapat diakses oleh seluruh masyarakat melalui Sistem Informasi Elektronik Desa Wisata Pujon Kidul (SIE Pujon Kidul).

Pokdarwis juga menerapkan pengelolaan yang bersifat transparan dan melibatkan warga masyarakat selaku monitoring dan evaluasi. Hal ini terlihat dari pembentukan kader Teknologi Informasidi tiap Rukun Tetangga (RT) untuk melakukan pemutakhiran data kependudukan, kesehatan, serta komoditas pertanian dan peternakan. Sedang untuk angka kunjungan dan pendapatan, masih dilakukan oleh divisi BUMdes yaitu Café Sawah dan Live in.

1. Partisipasi masyarakat yang terlihat;

- Partisipasi buah pikir, Kesadaran masyarakat Desa Wisata Pujon Kidul akan pariwisata kebermanfaatannya meningkat optimal ketika Pokdarwis berprestasi dan angka kunjungan wisatawan meningkat signifikan. Ditambah ketenaran di media social, muncul dalam Vlog Presiden Jokowi, menambah antusiasme warga. Mereka tertarik untuk membuka usahausaha pariwisat baru dari yang telah ada.

- Partisipasi Tenaga Fisik

Pelibatan masyarakat secara fisik dalam pengembangan fasilitas atau infrasruktur desa wisata, telah berjalan dengan sangat baik dan optimal. Karena kultur pedesaan yang masih kental dengan budaya gotong royongnya.

- Partisipasi keterampilan dan kemahiran

Keterlibatan keterampilan dan kemahiran masyarakat pada pengembangan dan kegiatan yang menunjang usaha wisata berbetuk seperti pemandu wisata.

- Partisipasi harta benda

Hampir seluruh fasilitas penunjang pariwisata merupakan milik desa dan dikelola serta dikembangkan oleh Pokdarwis. Sehingga kontribusi pelibatan masyarakat secara pasif 
melalui kontribusi asset pribadi hampir tidak ada.

Desa wisata Pujon Kidul dengan potensi wisata alam dan wisata edukasi aktivitas bertani, telah berkembang dan dikelola dengan sangat baik. Keberhasilan pengelolaan usaha wisata tersebut juga terlihat dari implikasi ekonomi berupa pendapatan desa juga masyarakat dari usaha pariwisata. Untuk kedepannya, usaha pariwisata yang telah berjalan perlu dikembangkan secara berkelanjutan dengan penerapan pembangunan berkelanjutan dengan tetap memperhatikan aspek-aspek ekomo, sosial budaya dan lingkungan, terutama terkait kepentingan masyarakat lokal.

\section{DAFTAR PUSTAKA}

Alfianto, Aditya Puji, 2017, Analisis Eksploratori Industri Kreatif Desa Wisata Dalam Perspektif Community Based Tourism (Studi Perbandingan pada Desa Wisata Gubugklakah dan Sanankerto, Kabupaten Malang), M.IA, Thesis : Jurnal Administrasi Bisnis (JAB)|Vol. 53 No. 1 Desember 2017

Google Maps

(https://www.google.co.id/maps/ place/Pujon+Kidul,+Pujon,+Malan g,+Jawa+Timur/@7.8896051,112.4572453,4677a,35y, $38.37 \mathrm{t} / \mathrm{data}=$ !3m1!1e3!4m5!3m4!1s ox2e78878eoec9obd3:0xe67fe39 dc6c94092!8m2!3d7.8565541!4d112.4619282)

Dinas Kebudayaan dan pariwisata Jawa Timur, 2015, Kebudayaan dan
Pariwisata Jawa Timur Dalam Angka 2015

Dinas Kebudayaan dan pariwisata Jawa Timur, 2015, Kebudayaan dan Pariwisata Jawa Timur Dalam Angka 2016

Dinas Kebudayaan dan pariwisata Jawa Timur, 2015, Kebudayaan dan Pariwisata Jawa Timur Dalam Angka 2017

Hadiwijoyo, Suryo Sakti. 2012. Perencanaan Pariwisata Pedesaan Berbasis Masyarakat. Yogyakarta: Graha Ilmu.

Hausler, N. S. W., 2003. Training Manual For Community-based Tourism. Zschortau:Inwent

Kemenparekraf, 2012, Pedoman Kelompok Sadar Wisata

Suansri, P., 2003. Community Based Tourism Hanbook. Thailand: Rest Project.

Syahid, Ahmad R., 2016, https://studipariwisata.com/refere nsi/definisi-pembangunanpariwisata-berkelanjutan-olehunwto

Yoeti, O. A., 1985. Pengantar Ilmu Pariwisata. Bandung: Angkasa.

http://pujonkidul.desa.id/, 2016, http://www.sie.pujonkidul.desa.id/, 2017 http://www.sie.pujonkidul.desa.id/, 2018

Prabowo,Septiofera Eresus, 2016, Analisis Partisipasi Masyarakat Dalam Pengembangan Desa Wisata (Studi Pada Desa Pujonkidul Kecamatan Pujon Kabupaten Malang), M.Ab., Thesis: Jurnal Administrasi Bisnis (JAB)|Vol. 33 No. 2 April 2016

Pitana, I Gde dan Putu G. Gayatri. 2005. Sosiologi Pariwisata. Yogyakarta: CV Andi Offset 